\title{
Studies in World Cinema: A Critical Journal
}

What if we are deprived of all content in the most post-apocalyptic manner? What if one starts writing about all the existing content at a time when there is no more of it to be produced - a moment of silence, of no more. Would we be happy with what we got so far or would we be able to find other ways of expressing the burning creative urge in ourselves through other media or forms? Such a moment that can come with the end of the digital media as we know it may seem to extinguish our options. Yet where, when, and how did storytelling start? Did it start the moment that humankind started speaking, uttering words? Or did it predate language and was purely visual? Did the cave paintings predate language or were they the dawning of the language itself? Perhaps it is impossible to answer such questions, but the thinking of the language is of expressing ourselves. Regardless of how it started, the urge to express, that creative impulse that exists, has been a driving force.

Two years ago, when this journal project started, the world, as we knew it, was as anticipated and apprehended as possible. Even during friendly discussions among some who think they are bombarded by arguably repetitive content, which was still there. If the content is out there, if there is more to be added to the existing body of it, and if the anticipation exists, all seemed fine. At such a point, the world signified something else. It was put simply as an adjective before a multitude of creative practices (including cinema, art, music, literature, and theater) and, as such, it signified either such practices traveling outside of their country of origin or such practices that belong to the non-English speaking and/or non-western countries. In both senses, despite the world, as a word, encompassed the entirety of the earth, it was rendered in a limited scope and in a relation to a variety of other words commonly used in relation to cinema, such as foreign, the other, subtitled, migrant, transnational, and the Third World.

However, as an epidemic that started at the end of 2019 turned into a pandemic in 2020, and the growing sense of anxiety and contempt, the lockdowns and curfews altered the sense(s) of the world. While the first half of 2020 reminded us that the "world" was a single entirety, the last quarter of 2020 once again reminded us that the world is no longer a single entity - but one divided by those who have the vaccine and who have not, the global North and others. 
Thus, we do not have a single sense of the world, but one which is divided, separated, and adjoined. It is only joined-to or -at something, which is the global North. As such the "world" as we know it is two-fold: one folded into itself in the global North and the second enfolding the others. Thus, any discussion of "world cinema" starts with such a two-folded sense of the world, one ad-joined and the other all-encompassing.

In the last two decades, the influx of multiculturalist and global perspectives in film studies put forward the second sense of the world, and multiple studies have focused on the interconnections and interrelations between multiple national cinematic frameworks. This led to an update of an earlier and a few decades old notion, "world cinema," and it is at times replaced by "transnational" and "migrant" cinema. But a few decades ago when "world cinema" was commonly used by different scholars, it also partially updated earlier notions such as Third cinema, subtitled art film, or international film. Seen in this regard, perhaps "world cinema" was one of the underlying attempts to challenge national cinema perspectives and to introduce issues of intercultural exchange and diasporic interventions. Earlier monographs dedicated to world cinema such as The Oxford History of World Cinema (Ed. by G. Nowell-Smith, 1997), World Cinema: Critical Approaches (Ed. by J. Hill et al., 2000), Remapping World Cinema (Ed. by S. Dennison and SH Lim, 2006), and Traditions in World Cinema (Ed. by L. Badley et al., 2006) touched on multiple matters of the films made and cinematic traditions existing outside the English-speaking countries and especially Hollywood cinema. On the other hand, while such an interest opened multiple venues to discuss and think on films from different parts of the world, there is also a drawback in this matter: the interest in "world cinema" is created, introduced, and developed in English by academics predominantly coming from the global North.

Put simply as an adjective before a multitude of creative practices (including cinema, art, music, literature, and theater), the "world" signifies either such practices traveling outside of their country of origin or such practices that belong to the non-English speaking and/or non-western countries. In both senses, despite the world, as a word, encompasses the entirety of the earth, it is rendered as in a limited scope in a relation to a variety of other words such as foreign, the other, subtitled, migrant, transnational, and Third World. Instead, swC hopes to introduce novel senses of the world by placing the world in relation to an evolving temporal and spatial experience of the world itself. In this sense, as separate from globalization, the world will be taken as a site of signification in which the cinematic works explore and reinvent its meaning and experience in a myriad of ways. Furthermore, while swc will also be limited to English language articles, it will attempt to introduce the work of the 
academics from the global South in the hope of opening up further avenues of discussion and understanding of world cinema.

In doing this, "what 'world cinema' is" will also be an integral part of the discussions that will be presented in swc. Yet, a limited sense of world cinema implies films from other and/or foreign countries which were shown in art house film theaters and television channels allocated to festival films. In other words, it implies the non-mainstream cinemas of the world. As the world has become smaller than ever in recent decades and as the influx and availability of other film cultures helped an intermingling of popular cinemas and their reception by a myriad of audiences, a newer sense of the "world cinema" will also entail a wider look at the popular film and television industries of the world.

Unlike the word "global," which implies a standardization and unification of the politics, economy, and cultures of the world, the word "world" presents a series of alternative senses and practices. Imagined as a process in which meaning, experience, and relations are in flux, this sense of the world implies a commonness and sharing. Thus, instead of qualifying cinema as global, cosmopolitan, universal, or international, the world cinema incurs a sense of the cinemas of the world, both by presenting an experience of them in a process and by forming diverse avenues of understanding them.

In its inaugural year, the journal will feature several invited articles which present contemporary renderings of world cinema, by presenting alternative approaches and takes on the concept, and thus by suggesting opinions or taking positions. These articles are also in part responses to a few questions that the editorial team prepared in charting out the current state of world cinema. They introduce issues in relation to the current state of world cinema, the modifying or signifying qualities of the "world" when used as an adjective or noun, the conceptual relations between the world and other notions such as international, global, multinational, or transnational, and finally the imagination of the world whether as a totality or as instances of multiple relations, differences, and separations. The articles, in return, present a multitude of takes not only on these questions but also invited multiple issues and concerns.

More specifically, they underline the need to reconsider the uni-directional movement of film culture and studies from the West to the rest and introduce a "dialogic" encounter (Gledhill); introduce the particular history of the notion in relation to "world literature" and "Third Cinema" (Mazierska); question the very notion of the world cinema, even its existence and its connection with the "human" earth (Brown); argue that while the early discussions on world and transnational cinema present divisive perspectives, there is a need for a "global frame" of world cinema (Jeung); present the discrepancies between the 
"totalistic" imagining of the notion and the actual socioeconomic and political separations that demarcate the world (Mazaj and Deshpande); discuss the commercial qualities of the notion and its relation to "global" (de Luca); examine its difference from and possible opposition to Hollywood as a separate market and also as a "label" (Parvulescu); introduce how cinema is metropolitan and connected to modernity and how, say, West African or Chinese films are relevant for the whole world beyond their national and regional demarcations (Andrew); introduce a three-fold signification of world cinema as the acknowledgement of multiple local cinemas, the artistic value attached to some of these on an international scale, and some specific films which could not be framed by borders (Frodon); speak of how popular national cinemas of the others, such as Brazilian or Turkish cinemas, are deemed as inferior yet also definitive in terms of national cultures (Peña); and suggest a new generic category in world cinema, the slow thriller linking mainstream cinema to arthouse filmmaking (Warner).

While this issue presents a multitude of opinions and positions concerning world cinema, it is just a beginning. I thank our associate editors (Ana Grgić, Olivia Khoo, and Jeremi Szaniawski), the Brill editorial team (Masja Horn and Robert van Gameren), and our editorial board, all of whom made this enthusiastic beginning possible. Starting from the second issue, Eva Jørholt will take over as the editor-in-chief and will continue to highlight world cinema as an "all-inclusive" concept. As the world is undergoing a debilitating phase, perhaps now is the time to discuss the issues raised by the films of world cinema, to have open eyes and ears to the lives of others, and to invite more and more critical input from diverse positions and locations. To this end, Studies in World Cinema: A Critical Journal offers a platform to examine, rethink, and reinvent the notion of "world cinema". What do we understand by "world cinema", and how useful or enabling is this term? Taking the world as a space of signification in which we continually reproduce its meanings, this journal opens up inquiries about films and cinematic practices that engender novel senses of the world. The journal welcomes research on traveling cinematic tropes, transnational practices, remakes and adaptations, translation cultures, migrant and diasporic films and film cultures, postcolonial and accented cinemas, collaborations and exchanges among filmmakers, co-productions and multinational filmmaking practices and networks, early cinematic practices, and other timebased media and screen productions such as television series, web series, and 
video installations. Together we aim to develop a fruitful and more enriching understanding of our world cinema.

\author{
Savaş Arslan \\ Editor-in-Chief of Studies in World Cinema, Dokuz Eylül University, Izmir, \\ Turkey \\ savas.arslan@deu.edu.tr
}

